\author{
MARLIN KILLEN \\ DREXEL UNIVERSITY, United States
}

\title{
THE IMPACT OF AUTHENTIC ASSESSMENT ON ACADEMIC PERFORMANCE, HIGHER ORDER THINKING, AND PERCEPTIONS OF AUTHENTICITY IN ONLINE UNDERGRADUATE PSYCHOLOGY COURSES
}

\begin{abstract}
:
Authentic pedagogy is a broad term that describes an active learning perspective with a focus on the construction of meaning and intellectual quality in the learning process. Although most of the work associated with authentic pedagogical approaches have been done in conjunction with elementary and secondary school reform, there is little research on the use of authentic pedagogical models of instruction in higher education, and even less research on models of authentic assessment.

This presentation will report on a study which examined the effect of authentic assessment on measures of academic performance, higher order thinking, and perceptions of authenticity in online undergraduate psychology courses. The presentation will discuss issues related to implementation of authentic assessment approaches in online course delivery and impact of this pedagogical model on learning outcomes in higher education.
\end{abstract}

\section{Keywords:}

Authentic Assessment, Higher Education, Online

JEL Classification: 120,129 